\title{
Study on the occurrence and abundance of noxious Microcystis spp. in pangasiid catfish (Pangasianodon hypophthalmus) ponds
}

\begin{abstract}
As microalgal blooms are very common and making serious problems in water bodies throughout Bangladesh, an investigation was carried out to see the composition and succession of noxious blue-green algae in pangasiid catfish (Pangasianodon hypophthalmus) ponds. During the course of the study, 20 species of Cyanophyceae were recorded, and among them Microcystis aeruginosa was the most abundant compared to other species. Significant occurrence of Microcystis viridis was also observed. Efforts were made to study certain physico-chemical factors and their influence on the composition and seasonal abundance of these species. Peak abundance of M. aeruginosa was observed from July to August. Moderately higher water temperature, lower rainfall and $\mathrm{NO}_{3}-\mathrm{PO}$ enrichment increased the biomass of both M. aeruginosa $\left(168.72 \times 10^{3} \mathrm{cell} / \mathrm{s} / \mathrm{L}\right)$ and $M$. viridis $\left(8 \times 10^{3} \mathrm{cells} / \mathrm{L}\right)$ in the experimental ponds. Higher feeding rate in monoculture of pangasiid catfish ( $P$. hypophthalmus) made the ponds hyper nutrified by unutilized feed and fish excreta that supported the higher abundance of these Cyanophyceae. In composite culture ponds, silver carp (Hypophthalmichthys molitrix) effectively grazed down the microalgae and as a result, algal bloom was not noticed.
\end{abstract}

Keywords: algal bloom, cyanophyceae, Microcystis aeruginosa, Microcystis viridis, pangasiid catfish
Volume 9 Issue I - 2020

\author{
Zinia Rahman,' Md Mahfuzul Haque, ${ }^{2}$ M \\ Aminur Rahman, ${ }^{3}$ Saleha Khan ${ }^{2}$ \\ 'Department of Genetics and Fish Breeding, Bangabandhu \\ Sheikh Mujibur Rahman Agricultural University, Bangladesh \\ ${ }^{2}$ Department of Fisheries Management, Bangladesh Agricultural \\ University, Bangladesh \\ ${ }^{3}$ Department of Fisheries and Marine Bioscience, Jashore \\ University of Science and Technology, Bangladesh
}

Correspondence: Saleha Khan, Professor, Department of Fisheries Management, Bangladesh Agricultural University, Bangladesh, Email salehakhan@bau.edu.bd

Received: November II, 2019 | Published: January 03, 2020

\section{Introduction}

Among the various cultural species of catfish, pangasiid catfish (Pangasianodon hypophthalmus) is particularly important for their fast growth, lucrative size, good taste and market demand..$^{1-3}$ This fish can be stocked at a much higher density in ponds compared to other culturable species in Bangladesh. ${ }^{1}$ As augmentation of fish production from rivers and estuaries is quite difficult, dependency on pond aquaculture has been increased for enhanced production and supply of fish, employment generation and poverty alleviation in the rural areas. Pangasiid catfish ( $P$. hypophthalmus) was highly accepted to the farmers during the introducing period because of its fast growth, disease resistance capacity and high consumer acceptance but in recent years, this fishery is gradually being depleted. Monoculture of pangasiid catfish ( $P$. hypophthalmus) is mainly practiced in Bangladesh where for profitable production within a short growing cycle, over stocking of fast growing mono species is being practiced utilizing higher doses of supplemental feed. But within few years of successive culture, farmers faced a bitter experience, most of the culture ponds became hypernutrified which in extreme cases caused eutrophication by algal population due to continuous deposition of nutrients from unutilized natural food, excessive supplementary feed, uneaten portion of feed and excretory products.

For efficient management and successful culture practices, the aqua biologists always confront the problems of productivity of water bodies. Although microalga is an essential component of aquatic ecosystem, it should be in an optimum range to ensure proper productivity. Large number of microalgae can produce bloom, which sometimes can have a detrimental effect on aquatic organisms. ${ }^{4}$ In many ponds, blue-green algae constitute the greater part of the algal biomass during summer and substances produced by many species of Cyanophyceae are toxic to aquatic plants and animals. ${ }^{5}$ So, algal bloom is not always desirable because of toxin, which can deteriorate the water quality and can cause toxicity to fish population and may lead to mass mortality of fishes. ${ }^{6}$ Eutrophication and bloom of various algal groups, mainly cyanobacteria deteriorate water quality and cause harm to fish population and ultimately economic loss in pangasiid catfish (P. hypophthalmus) farming. The contribution of cyanobacteria to various aspects of ecosystem function has received considerable attention. ${ }^{7}$ Chronic exposure of fish to toxic algal blooms in pangasiid catfish ( $P$. hypophthalmus) ponds may result in ionic imbalance and reduced growth with oxygen deficiency and inhibition of light penetration. ${ }^{8}$ Thus, eutrophication associated with other hydrological parameters make the environment friendly for the mass occurrence of toxic and noxious algal blooms, which posing threat to aquatic life.

Environmental factors interact to regulate spatial and seasonal growth and succession of microalgal populations. Algae have definite temperature optima and tolerance ranges, which interact with other parameters to cause seasonal succession. Though the different seasons of a year in Bangladesh are not so marked as those of temperate countries, yet considerable variations of population density of microalgae are found. The common species in one month are often become the rare species in the following month. Abrupt changes in abiotic factors (e.g., wind-induced vertical mixing; marked seasonality in rainfall and associated nutrient loading and turbidity) can be more frequent in tropical lakes which leads to a series of numerous episodic changes in the annual phytoplankton succession and productivity. ${ }^{9} \mathrm{~A}$ good number of research were done on eutrophication, algal blooms and seasonal succession of phytoplankton throughout the world but there is a scarcity of work on microalgal species composition, temporal succession and algal blooms and their effects on pangasiid catfish ( $P$. hypophthalmus) production. ${ }^{10-13}$ With the progress of pond aquaculture, studies of the microalgae occurring in pond has gained considerable importance. The qualitative and quantitative variation of phytoplankton in different months is likely to have direct effect on fish 
growth. So, their species composition and seasonal trends are of great value. The growth of Microcystis produces bad odour and unsightly scum, preventing recreational use of water bodies, hampering treatment of water for drinking, and clogging irrigation pipes. ${ }^{14}$ This underscores the need for investigation on the occurrence of noxious Microcystis aeruginosa and Microcystis viridis in pangasiid catfish $(P$. hypophthalmus) ponds to observe structure of Microcystis community and their seasonal flux, species composition, effectiveness of silver carp (Hypophthalmichthys molitrix) in water quality maintenance through grazing down the algae, and the quantitative and qualitative variations of these two species in respect to the physico-chemical factors and abundance of fish species.

\section{Materials and methods}

\section{The study area}

All the ponds were situated side by side in the same area which were newly excavated and rain-fed and of rectangular shape with an area of $200 \mathrm{~m}^{2}$ each in the Field Laboratory of the Faculty of Fisheries, Bangladesh Agricultural University, Mymensingh, Bangladesh.

\section{Experimental design}

Fishes were stocked at a density of 120 fishes per decimal. The experiment was arranged in three treatments each with three replications. In treatment I (T-I), 120 pangasiid catfish $(P$. hypophthalmus) were stocked, in treatment II (T-II) and treatment III (T-III), 60 pangasiid catfish ( $P$. hypophthalmus) +60 silver carp (Hypophthalmichthys molitrix) and 80 pangasiid catfish (P. hypophthalmus) +40 silver carp (H. molitrix) were stocked, respectively. Commercial pellet feed was given considering only the body weight of pangasiid catfish (P. hypophthalmus). Silver carp $(H$. molitrix) normally cannot eat pellet feed and they grow on natural feed, plankton. Feeding rate was $10 \%$ of the body weight of fish (first month - May), $8 \%$ of the body weight of fish (first fortnight of June), $6 \%$ of the body weight of fish (second fortnight of June to July), 5\% of the body weight of fish (August). Pond experiment was done over 105 days. Pangasiid catfish (P. hypophthalmus) and silver carp $(H$. molitrix) seeds were collected from a local renowned fish fry trader.

\section{Water quality parameters}

One sampling point for each pond was selected. Water temperature and colour of water were observed daily, and nitrate-nitrogen, phosphate-phosphorus and phytoplankton population measured fortnightly as stated by Affan et al. ${ }^{15}$ Rainfall data were collected from the Weather Office, Bangladesh Agricultural University, Mymensingh, Bangladesh.

\section{Study of phytoplankton}

Five liters of water from each pond were collected from different zones and concentrated to $100 \mathrm{ml}$ by passing through a No. 25 bolting silk plankton net. The collected phytoplankton samples were stored in vials and preserved in 5\% buffered formalin for future qualitative and quantitative analyses. A microscope calibrated with a Whipple ocular micrometer was used in the qualitative study, and identification of planktons was done up to genus and species level where possible according to Ward \& Whipple, ${ }^{16}$ Needham \& Needham, ${ }^{17}$ Prescott, ${ }^{18}$ APHA $^{19}$ and Bellinger. ${ }^{20}$ The estimation of phytoplankton was done by Sedgwick-Rafter counting chamber (S-R cell) method under an Olympus (model B061) microscope. ${ }^{21}$ Counted results were summarized as cells per liter.

\section{Statistical analysis}

For statistical analysis of data, a one-way ANOVA was carried out using MSTATC statistical package. ${ }^{22}$ Statistical significance level was estimated at $P<0.05$ and $P<0.01$.

\section{Results and discussion}

\section{Total phytoplankton}

Microalgal species diversity in lacustrine ecosystems is influenced by many biotic and abiotic processes that include the magnitude and frequency of inflow events, associated with nutrient loading, infection by species-specific pathogens and selective grazing by fish. ${ }^{23}$ During the course of present investigation in the natural assemblage of microalgae in pangasiid catfish (P.hypophthalmus) ponds, 45 species were recorded, of which 20 belonged to Cyanophyceae, 14 to Chlorophyceae, 8 to Bacillariophyceae and 3 to Euglenophyceae (Table 1). Hossain ${ }^{24}$ recorded a total of 38 microalgal genera when studied biological production of ponds. Rahman ${ }^{25}$ found 39 genera of microalgae belonging to Cyanophyceae (10spp.), Chlorophyceae (19spp.), Bacillariophyceae (7spp.) and Euglenophyceae (3spp.) in the research ponds of Bangladesh Agricultural University, Mymensingh. Kohinoor et al. ${ }^{26}$ recorded 34 genera of microalgae belonging to these four groups: Cyanophyceae, Chlorophyceae, Bacillariophyceae and Euglenophyceae. Affan et al. ${ }^{15}$ observed a total of 45 phytoplankton species from four ponds situated in the surroundings of Bangladesh Agricultural University, Mymensingh and those consisted of Cyanophyceae (30spp.), Chlorophyceae (7spp.), Bacillariophyceae (5spp.) and Euglenophyceae (3spp.). The variation in number of species among the results of the different studies could arise from the difference in the nutrient status, chemical qualities of water and density and species composition of fish stocked. In all the treatments, abundance of Cyanophyceae was observed to be higher except in T-II (Figure 1). In T-II, Chlorophyceae ranked highest (41.34\%) followed by Cyanophyceae $(33.06 \%)$, may be due to the effective grazing of Cyanophyceae by the silver carps.

Table I List of phytoplankton recorded from the pangasiid catfish ( $P$. hypophthalmus) farming ponds

\begin{tabular}{ll}
\hline Cyanophyceae & Chlorophyceae \\
\hline Microcystis aeruginosa & Oedogonium \\
Microcystis viridis & Scenedesmus \\
Microcystis wesenbergii & Volvox \\
Microcystis flos-aquae & Ulothrix \\
Anabaena crassa & Zygnema \\
Anabaena curva & Synedra \\
Anabaena fusca & Coelastrum \\
Anabaena heterospora & Botryococcus \\
Anabaena levandari & Pediastrum \\
Anabaena lemmermanii & Spirogyra \\
Anabaena macrospora & \\
\hline
\end{tabular}


Table Continued..

\begin{tabular}{ll}
\hline Aanabaenopsis & Bacilariophyceae \\
\hline Merismopedia warminghiana & Cyclotella \\
Aphanizomenon flos-aquae & Navicula \\
Oscillatoira & Nitzschia \\
Chroococcus & Coscinodiscus \\
Nostoc & Tabellaria \\
Gomphosphaeria & Asterionella \\
Aphanocapsa & Gyrosigma \\
Nodularia & Pleurosigma \\
Chlorophyceae & Euglenophyceae \\
Actinastrum & Euglena \\
Ankistrodesmus & Phacus \\
Chlorella & Trachelomonas \\
Closterium & \\
\hline
\end{tabular}

\section{Abundance of Cyanophyceae}

The dynamics of phytoplankton succession is a function of many of the environmental processes that affect particular species diversity. Blue-green algae were observed as the most dominant group among the phytoplankton and maintained its dominance throughout the study period, which agrees with the findings of Rahmatullah et al. ${ }^{27}$ The percent compositions of Cyanophyceae occupied 49.83\%, 33.06\% and $49.25 \%$ in total phytoplankton in T-I, T-II and T-III, respectively (Figure 1). Their dominance was due to their abundance in number, not in species. The highest abundance of Cyanophyceae was $168.72 \times 10^{3} \mathrm{cells} / \mathrm{L}$ on 31 July in T-I, $77.06 \times 10^{3} \mathrm{cells} / \mathrm{L}$ on $15 \mathrm{June}$ in T-II and $151.56 \times 10^{3}$ cells/L on 31 July in T-III. Significant differences $(P<0.05)$ were found with the abundance of Cyanophyceae among the treatments (Figure 2).

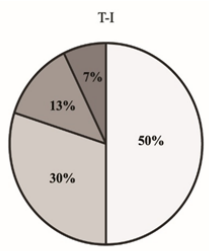

๑yanophyceae

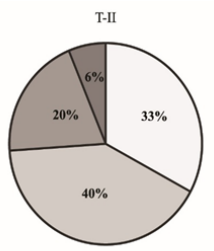

๑Chlorophyceae
๑Bacillariophyceae

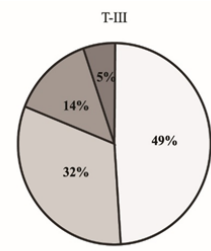

๑Euglenophyceae
Figure I Percent composition of different groups of microalgae found in the ponds under three different treatments.

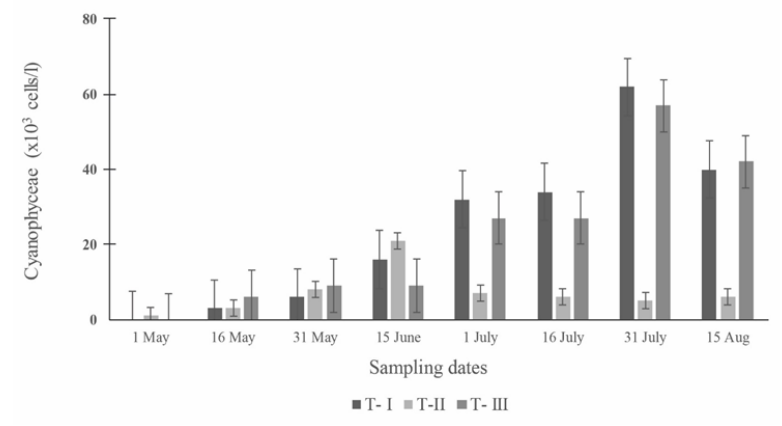

Figure 2 Abundance of Cynophyceae in ponds under three different treatments.
As there was no silver carp (H. molitrix) in ponds of T-I, Cyanophyceae cell density was high compared to T-II and T-III. Microalgae were found to persist in the surface water as thick scum in ponds of T-I due to their higher abundance. Excessive blooms of blue-green algae are particularly common in ponds used for intensive culture of channel catfish. ${ }^{28}$ But in T-II and T-III, abundance of Cyanophyceae was comparatively lower than T-I and that might be due to the presence of silver carp (H. molitrix). In T-II, lower abundance of Cyanophyceae was observed because of the grazing effect of silver carp (H. molitrix). Siddiqua ${ }^{29}$ found highest percentage of cyanobacteria in the gut content of silver carp (H. molitrix). In ponds with high feeding rates, blue-green algae on the average was more numerous than other types of algae. Silver carp (H. molitrix) grazed on phytoplankton more effectively in T-II. A number of problems, including odours,,$^{30}$ bad taste in fish,,$^{31}$ presence of toxic substance and shallow chemical and thermal stratification of pond waters ${ }^{32}$ have been attributed to blooms of blue-green algae. Furthermore, under certain conditions, blooms of blue green algae, particularly species of Microcystis and Anabaena, suddenly die and their decomposition leads to oxygen depletion and fish mortality. ${ }^{30,33}$ Thick algal blooms of cyanobacteria inhibit light penetration as well as they use most of the nutrients from the water body for their growth. As a result, the growth of other beneficial planktons decreased markedly and ultimately hampered the fish production in the present study.

\section{Dominance of Microcystis aeruginosa}

In the present study, Cyanophyceae comprised of 11 genera and the much higher abundance of Microcystis was observed in comparison to other genera. This was might be due to inhibitory effect of this genus on other genera. The inhibition of growth of Chlorella by Microcystis was proved by the inverse correlation among them in all the ponds. Similar trend was recorded in case of Euglena and Microcystis. Habib et al. ${ }^{34}$ recorded that Microcystis and Anabaena had inverse relation with most of the other microalgae. The inhibition of growth may be due to the production of toxins of other microalgae which agrees with the findings of Lam and Silvester. ${ }^{35}$

Microcystis aeruginosa is one of the most cosmopolitan species among the planktonic cyanobacteria. Significant differences were found in the abundance of $M$. Aeruginosa among the treatments $(P<0.05)$ (Figure 3). It was observed as the most dominant species in the present investigation. In T-I, the highest number $\left(62 \times 10^{3} \mathrm{cells} / \mathrm{L}\right)$ of $M$. aeruginosa was observed on 31 July which decreased to $40 \times 10^{3} \mathrm{cells} / \mathrm{L}$ on 15 August. However, they were not found on 1 May, at the start of the investigation. In T-II, the highest number of M. aeruginosa was observed as $21 \times 10^{3}$ cells/L on 15 June, followed by $8 \times 10^{3} \mathrm{cells} / \mathrm{L}$ on 31 May and the lowest number of $1 \times 10^{3}$ cells $/ \mathrm{L}$ was noted on the started date of the experiment. In T-III, the highest number of $57 \times 10^{3}$ cells/L was found on 31 July, followed by $42 \times 10^{3} \mathrm{cells} / \mathrm{L}$ on 15 August but they were not found on 1 May as shown in Figure 3. Microcystis aeruginosa was dominated by $95-98 \%$ of the total phytoplankton density during the bloom. ${ }^{36}$

Kruger and Eloff ${ }^{37}$ stated that the temperature for optimum growth of Microcystis is between 29 and $30.5^{\circ} \mathrm{C}$, so the recorded temperature and lower rainfall during the present study were favourable for the high concentration of the species (Figure 4\&5). Murrel and Lores ${ }^{38}$ reported that $M$. aeruginosa dominance often occurs when the temperature rises above $20^{\circ} \mathrm{C}$. This finding is also similar to Visseret al..$^{39}$ under culture condition. Another cause of higher abundance of M. aeruginosa might be due to favourable hydrographical conditions. 
Affan et al. ${ }^{40}$ suggested that high concentrations of $\mathrm{NO}_{3}-\mathrm{N}$ influenced toxin production by increasing $M$. aeruginosa propagation. The number of $M$. aeruginosa was found to be increased with the increasing level of $\mathrm{NO}_{3}-\mathrm{N}$ and $\mathrm{PO}_{4}-\mathrm{P}$ concentrations (Figure 6). Higher phosphorus content of surface water was reported to be the reason for a bloom of the cyanobacteria, $M$. aeruginosa. ${ }^{14}$
The inhibition of growth of other microalgae may be due to the toxin produced by the Microcystis. ${ }^{41}$ Microcystis aeruginosa inhibited the growth of several species in laboratory cultures and apparently reduced the production of other algae in three Missouri ponds. ${ }^{42}$ Microcystis played a dominant role to create bloom. Dominancy of Microcystis have also been reported by Habib et al., ${ }^{34}$ Ali et al., ${ }^{43}$ Cunqi et al. ${ }^{44}$ and Jahan et al. ${ }^{45}$

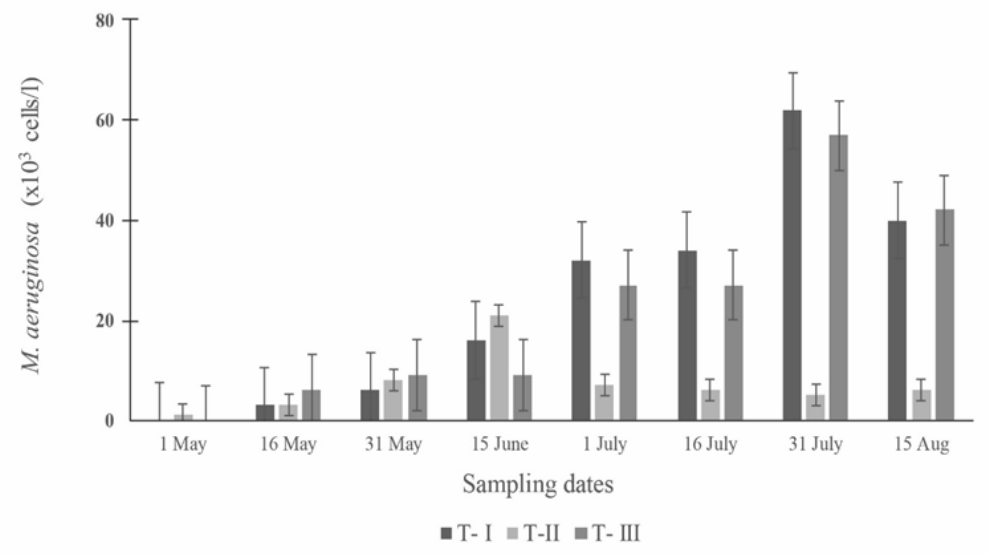

Figure 3 Abundance of $M$. aeruginosa in ponds under three different treatments.

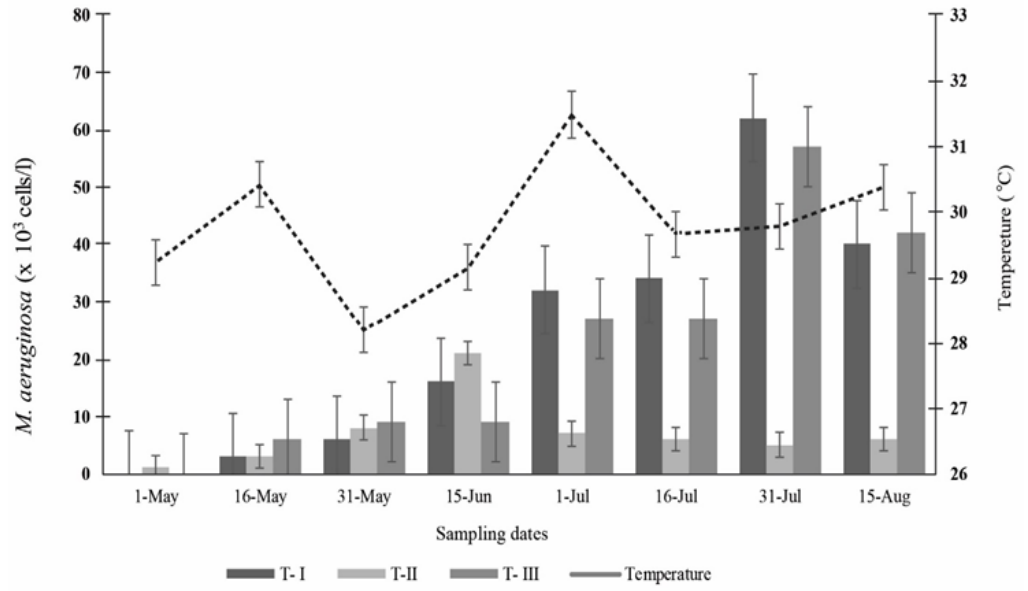

Figure 4 Influence of temperature on M. aeruginosa abundance in ponds under three different treatments.

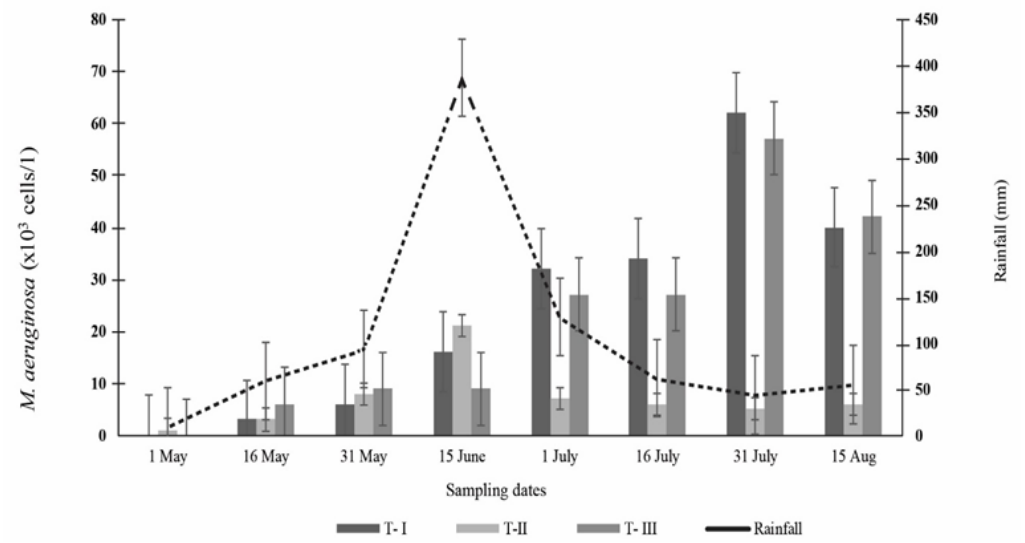

Figure 5 Influence of rainfall on M. aeruginosa abundance in ponds under three different treatments. 

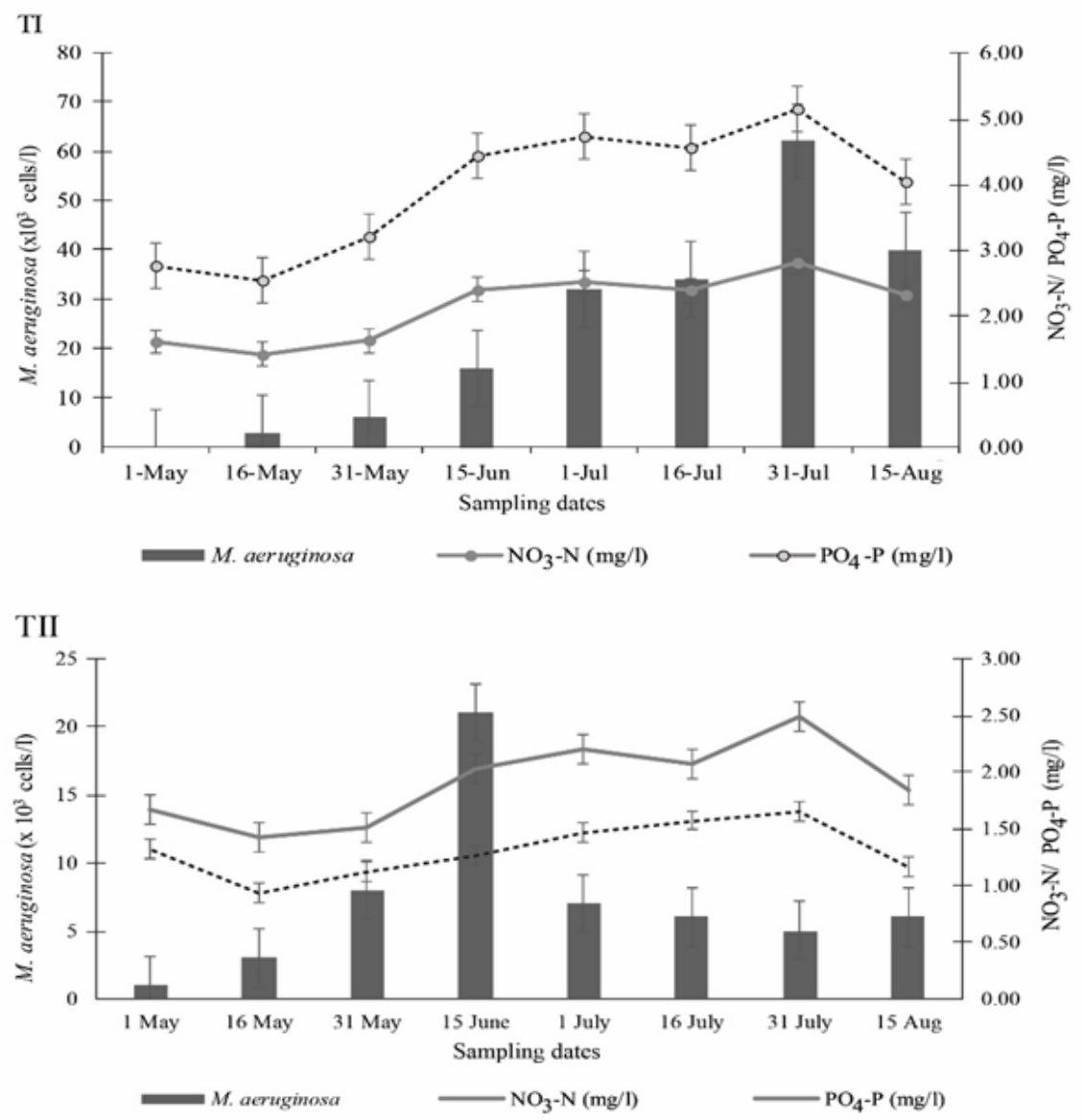

TIII

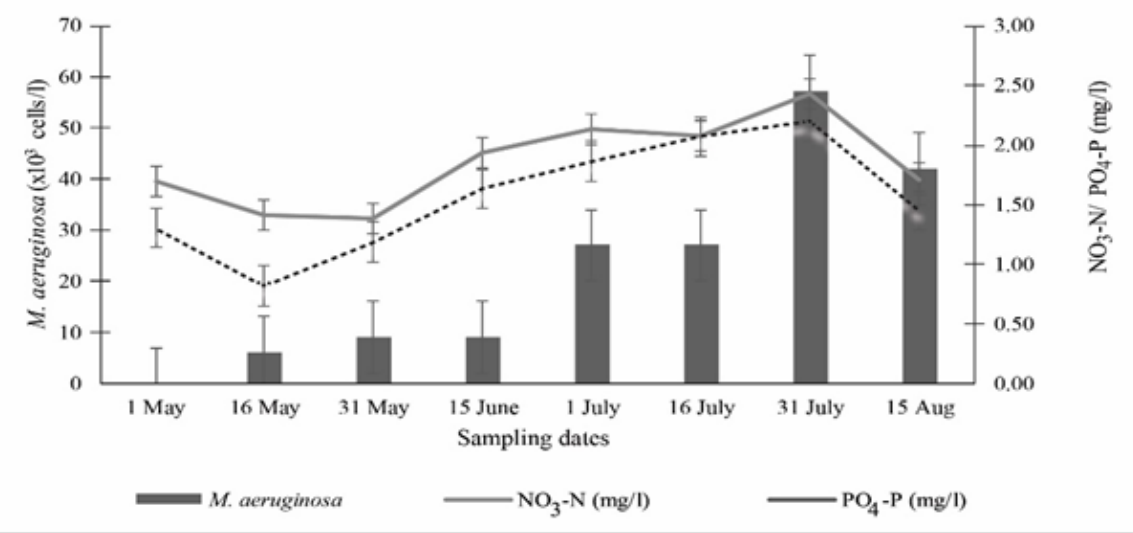

Figure 6 Influences of $\mathrm{NO}_{3}-\mathrm{N}$ and $\mathrm{PO}_{4}-\mathrm{P}$ on $\mathrm{M}$. aeruginosa production in ponds under three different treatments.

\section{Dominance of Microcystis viridis}

Significant differences $(P<0.05)$ were found in the abundance of $M$. viridis among the treatments (Figure. 7). In treatment I, the highest number of $M$. viridis $\left(8 \times 10^{3} \mathrm{cells} / \mathrm{L}\right)$ was observed on 16 July followed by $6 \times 10^{3} \mathrm{cells} / \mathrm{L}$ on $1 \mathrm{July}$. However, they were not available in May. Microcystis viridis was occasionally present in other two treatments during the months of July and August. They were not found in May in other treatments too (Figure 7). Major changes in the abundance of microalgae in tropical ponds are related to change in availability of phosphorus and nitrogen and they likely to play a significant role in succession and competitive success of certain algal populations (Figure 8). Much lower abundance of $M$. viridis was observed in comparison to $M$. aeruginosa in the present study. This was might be due to inhibitory effect of $M$. aeruginosa on other species. The inhibition of growth may be due to the production of toxins of other microalgae which agreed with the findings of Lam and Silvester. ${ }^{35}$ The inhibition of growth of Chlorella by Microcystis was proved by the inverse correlation among them in all the ponds. Similar trend was recorded in case of Euglena and Microcystis. Habib et al. ${ }^{34}$ recorded that Microcystis and Anabaena had inverse relation with most of the other microalgae. 


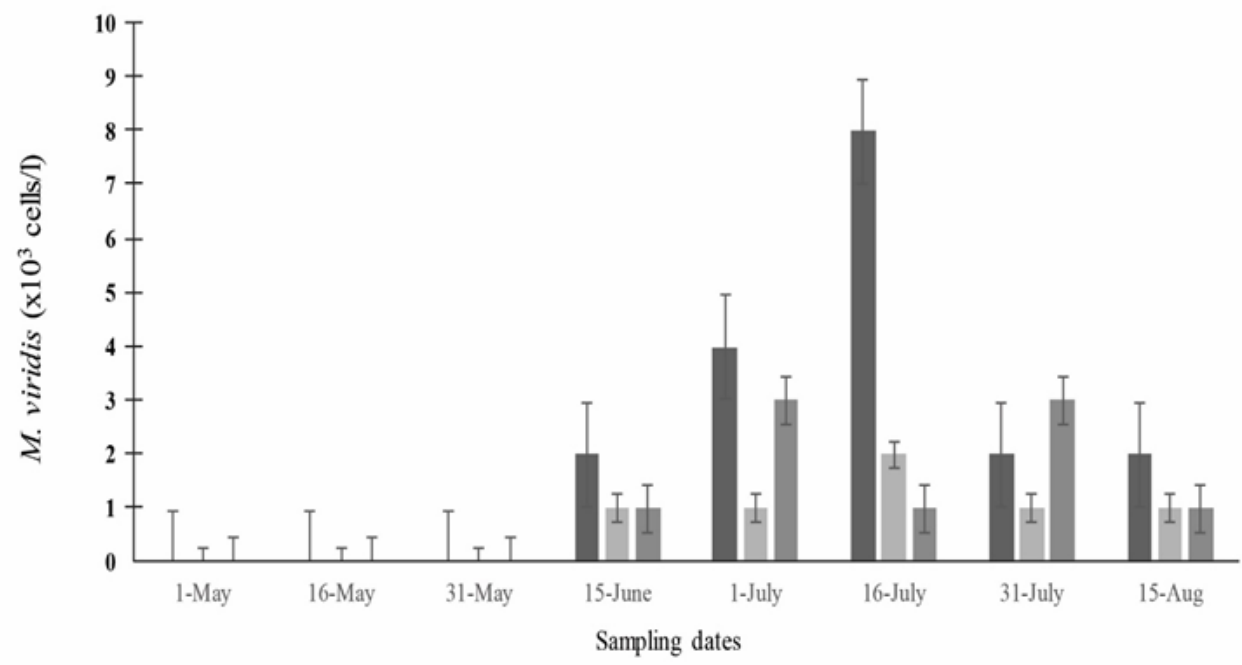

घ-I $\| \mathrm{T}$-II $\quad$ T- III

Figure 7 Abundance of $M$. viridis $\left(\times 10^{3}\right.$ cells/l) in ponds under three different treatments.
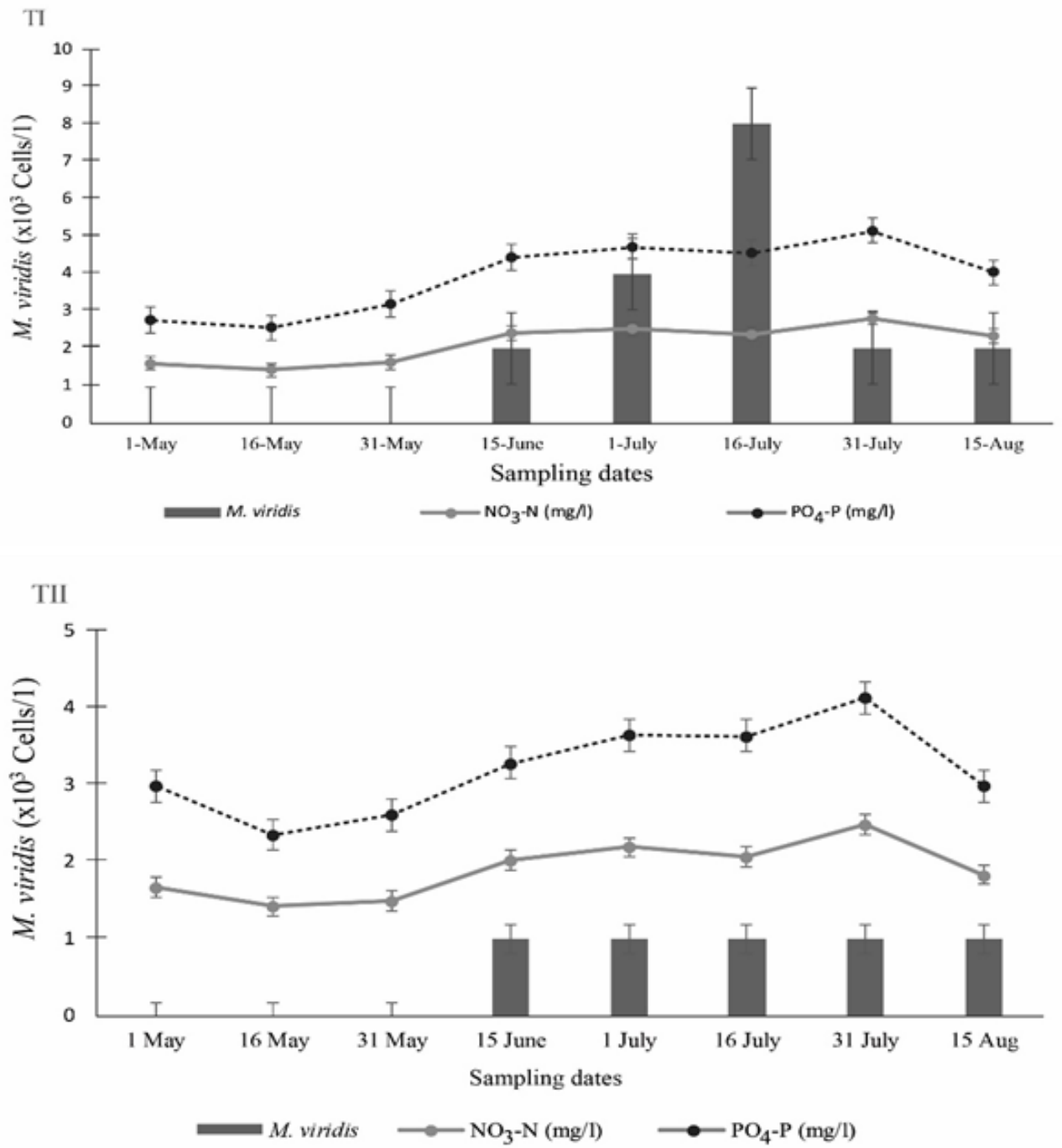


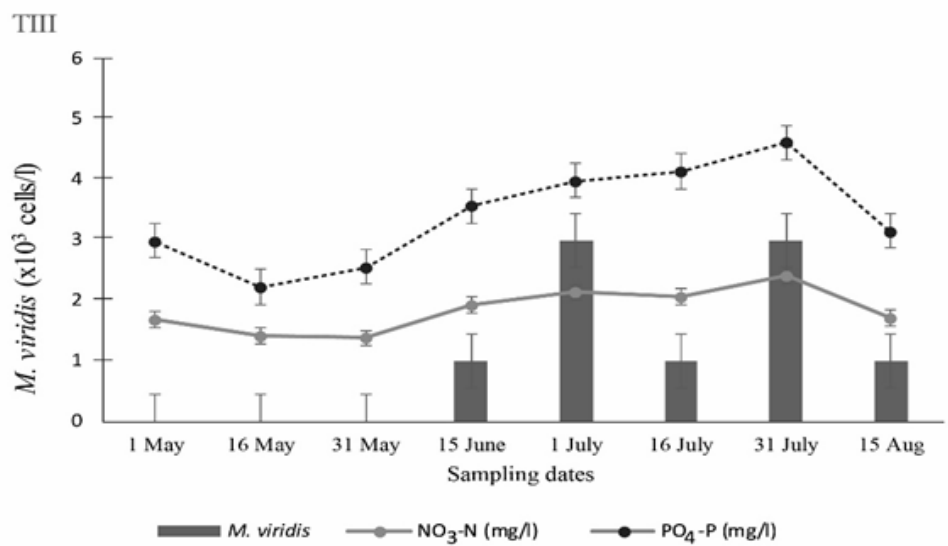

Figure 8 Influences of $\mathrm{NO}_{3}-\mathrm{N}$ and $\mathrm{PO}_{4}-\mathrm{P}$ on $M$. viridis in ponds under three different treatments.

\section{Conclusion}

In the natural assemblage of pangasiid catfish ( $P$. hypophthalmus) farming ponds, the microalgal population was identified and found to be composed of 45 phytoplankton genera belonging to four major groups. Microcystis aeruginosa was observed as the most dominant species and caused bloom in ponds of pangasiid catfish ( $P$. hypophthalmus) monoculture as high nutrient contents and other favourable environmental conditions seriously enhanced the growth with a peak in the summer months. As there was no silver carp ( $H$. molitrix) in monoculture of pangasiid catfish ( $P$. hypophthalmus) ponds, microalgae could not be used as food and they remained in the ponds and caused eutrophication and bloom by maximizing their abundance. In the ponds of composite culture, silver carp (H. molitrix) effectively grazed on microalgae and prevented algal bloom, and water quality was found better than the monoculture ponds. Therefore, from this evidence in hand, it is suggested that silver carp (H. molitrix) can be introduced in pangasiid catfish ( $P$. hypophthalmus) ponds as a means of biological control of microalgae, which would help in improving the aquatic environment as well as fish yield. Nevertheless, aquatic environmental monitoring in pangasiid catfish ( $P$. hypophthalmus) ponds with special emphasis on microalgal species composition and their dynamics in different regions and different seasons are suggested for better management practices.

\section{Acknowledgements \& funding}

None.

\section{Conflicts of interest}

The authors declare that there are no conflicts of interest

\section{References}

1. Sarkar MRU, Khan S, Haque MM, et al. Pangasiid catfish Pangasius hypophthalmus farming in Bangladesh: a rural survey in the Mymensingh region. Journal of Marine Bioscience and Biotechnology. 2007;2(2):94101

2. Sarkar MRU, Khan S, Haque MM, Haq MS. Evaluation of growth and water quality in pangasiid catfish (Pangasius hypophthalmus) monoculture and polyculture with silver carp (Hypophthalmichthys molitrix). Journal of the Bangladesh Agricultural University. 2006; 4(2):339-346.

3. Khan S, Hossain MS, Haque MM. Effects of feeding schedule on growth, production and economics of pangasiid catfish (Pangasius hypophthalmus ) and silver carp (Hypophthalmichthys molitrix) polyculture. $J$. Bangladesh Agril Univ. 2009;7(1):175-181.
4. Carmichael WW, Falconer IR. Disease related to freshwater algal toxins, and control measures. In: Falconer IR, editor. Algal toxins in sea food and drinking water. Academic Press. London. 1993. p.187-209.

5. Sevrin-Reyssac J, Pletikosonic M. Cyanobacteria in fish ponds. Aquaculture. 1990;88(1):1-20.

6. Kaarina S. Cyanobacterial toxins and toxin production. Phycologia. 1996;35:12-24.

7. Chan F, Marino RL, Howarth R, et al. Ecological constraints on planktonic nitrogen fixation in saline estuaries. II. Grazing controls on cyanobacterial population dynamics. Marine Ecology Progress Series. 2006;309:41-53.

8. Bury NR, Eddy FB, Codd GA. The effects of the Cyanobacterium Microcystis aeruginosa, the Cyanobacterial hepatotoxin microcystin-LR and ammonia on growth rate and ionic regulation of brown trout. Journal of Fish Biology. 1955;46(6):1042-1054.

9. Melack JM. Temporal variability of phytoplankton in tropical lakes. Oecologia. 1979;44:1-7.

10. Murendeni M, Oberholster PJ, Shonhai A, et al. The presence of toxic and non-toxic cyanobacteria in the sediments of Limpopo river basin: implications for human health. Toxins. 2018;10(7):269.

11. Frazao B, Martins R, Vasconcelos V. Are known cyanotoxins involved in the toxicity of picoplanktonic and filamentous North Atlantic marine cyanobacteria? Mar Drugs. 2010;8(6):1908-1919.

12. Gumbo RJ, Ross G, Cloete ET. Biological control of Microcystis dominated harmful algal blooms. African Journal of Biotechnology. 2008;7(25):47654773 .

13. O'Neil JM, Davis TW, Burford MA, et al. The rise of harmful cyanobacteria blooms: the potential roles of eutrophication and climate change. Harmful Algae. 2012;14:313-334.

14. Miyazaki T, Tainaka K, Togashi T, et al. Spatial coexistence of phytoplankton in ecological timescale. Population Ecology. 2006; 48(2):107-112.

15. Affan A, Jewel AS, Haque M, et al. Seasonal cycle of phytoplankton in aquaculture ponds in Bangladesh. Algae. 2005;20:43-52.

16. Ward HB, Whipple GC. Freshwater Biology. John Willey and Sons Inc., New York.1954;128 p.

17. Needham JG, Needham PR. A guide to the study of freshwater biology. 5th ed. Holden-Day Inc., San Francisco. 1962; 106 p.

18. Prescott GW. Algae of the western Great lakes area. Wm. C. Brown. Co, Inc. Dubuque. Iowa. 1964; 946 p.

19. APHA. Standard methods for the examination of water and waste water. American Public Health Association, New York. 1992; 874 p. 
20. Bellinger EG. A key to common algae: Freshwater, estuarine and some coastal species. The Institute of Water and Environment Management. London, UK. 1992; 138 p.

21. Stirling HP. Chemical and Biological methods of water analysis for Aquaculturists. Institute of Aquaculture, University of Stirling, Scotland. 1985; 119 p.

22. Sokal RR, Rohlf FJ. Biometry. 2nd ed. W.H. Freeman and Co., New York. $1981 ; 859$ p.

23. Figueredo CC, Giani A. Seasonal variation in the diversity and species richness of phytoplankton in a tropical eutrophic reservoir. Hydrobiologia. 2001; 445(1-3):165-174.

24. Hossain MY. Effects of iso-phosphorus organic and inorganic fertilizers on water quality parameters and biological production. M.S. Thesis. Department of Fisheries Management, Bangladesh Agricultural University, Mymensingh, Bangladesh. 2000; 83 p.

25. Rahman MM. Effect of species combination on pond ecology and growth of fish in carp-SIS polyculture systems. M.S. Thesis, Department of Fisheries Management, Faculty of Fisheries, Bangladesh Agricultural University, Mymensingh, Bangladesh. 1999;92 p.

26. Kohinoor AHM, Islam ML, Wahab MA, et al. Effect of mola (Amblypharyngodon mola) on the growth and production of carps in polyculture. Bangladesh Journal of Fisheries Research. 1998;2(2):119126.

27. Rahmatullah SM, Islam MA, AliM. The qualitative and quantitative studies of phytoplankton of a pond within the Bangladesh Agricultural University campus, Mymensingh. Bangladesh Journal of Aquaculture. $1983 ; 2-5(1): 43-49$

28. Boyd CE. Water quality management for pond fish culture. Elsevier Sci. Publ. Co. Amsterdam-Oxford- New York. 1982; 318p.

29. Siddiqua A. The occurrence and abundance of cyanobacteria (bluegreen algae) in aquaculture ponds and their role in fish production. M.S. Thesis. Department of Fisheries Management, Bangladesh Agricultura University, Mymensingh. 2002; 135 p.

30. Shilo M. Biological agents which cause lysis of blue-green algae. Mitt. Internat. Verein. Limnol. 1971;19:206-213.

31. Lovell RT, Sackey LA. Adsorption by channel catfish of earthy-musty flavour compounds synthesized by cultures of blue-green algae. Transactions of the American Fisheries Society. 1973;102(4):774-777.

32. Beasley PG. The penetration of light and concentrations of dissolved oxygen in fertilized pond waters infested with Microcystis. Proc. Ann. Conf. Southeast. Assoc. Game and Fish Comm. 1965;17:222-226.
33. Swingle HS. Standardization of chemical analysis for water and pond muds. FAO Fish Rep. 1967;4(44):397-421.

34. Habib OA, Tippett R, Murphy KJ. Seasonal changes in phytoplankton community structure in relation to physico-chemical factors in Loch Lomond, Scotland. Hydrobiologia. 1997;350:63-79.

35. Lam C, Silvrster WB. Growth interactions among blue-green (Anabaena oscillarioides, Microcystis aeruginosa) and green-algae (Chlorella). Hydrobiologia. 1979;63(2):135-143.

36. Prasath B, Kumar N, Thillainayagam J, et al. First report on the intense cyanobacteria Microcystis aeruginosa Kützing, 1846 bloom at Muttukkadu Backwater, Southeast coast of India. Indian Journal of GeoMarine Sciences. 2014;43(2):258-262.

37. Kruger GHJ, Eloff JN. The effect of physico-chemical factors on growth relevant to the mass culture of axenic Microcystis. In: Charmichael WW, editor. The Water Environment, Algal Toxin and Health. Plenum Press, New York, 1981; 193-222.

38. Murrell MC, Lores EM. Phytoplankton and zooplankton seasonal dynamics in a subtropical estuary: importance of Cyanobacteria. Journal of Plankton Research. 2004;26(3):371-382.

39. Visser PM, Ketelaars HAM, Mur LR. Reduced growth of the cyanobacterium Microcystis in an artificially mixed lake and reservoir. Water Science \& Technology. 1995;32(4):53-54.

40. Utkilen H, Gjolme N. Toxin production by Microcystis aeruginosaas a function of light in continuous cultures and its ecological significance. Appl Environ Microbiol. 1992;58(4):1321-1325.

41. Affan MA, Touliabah H, Al-Harbi SM, et al. Influence of environmental parameters on toxic cyanobacterial bloom occurrence in a lake of Bangladesh. Rend Fis Acc Lincei. 2016;27(3):473-481.

42. Vance BD. Composition and succession of cyanophycean water blooms. Journal of Phycology. 1965;1(2):81-86.

43. Ali MM, Rahmatullah SM, Habib MAB. Interspecific correlation in some dominant species of phytoplankton. Bangladesh Journal of Microbiology. 1986; 3(2):29-36.

44. Cunqi L, Lusan L, Huitao S. Seasonal variations of phytoplankton community structure in relation to physico-chemical factors in Lake Baiyangdian, China. Procedia Environmental Sciences. 2010;2:16221631

45. Jahan R, Khan S, Haque MM, et al. Study of harmful algal blooms in a eutrophic pond, Bangladesh. Environmental Monitoring and Assessment. 2010;170:7-21 